\title{
The Use Of Snowballing Technique To Learn Applying Vocabulary After The Pandemic
}

\author{
${ }^{1}$ Tri Setianingsih, ${ }^{2}$ Siti Syafi'atul Qomariyah, ${ }^{3}$ Bq. Zuhrotun Nafisah \\ ${ }^{123}$ English Teacher, Faculty of Culture, Management and Business, Mandalika University of \\ Education, Indonesia \\ Co. Author Email: trisetianingsih@undikma.ac.id
}

\begin{abstract}
The Use of Snowballing Technique to Learn Applying Vocabulary After the Pandemic. This research is aimed at finding out the effectiveness of using snowballing technique to learn applying vocabulary at the third grade students of SMAN 1 Batulayar in academic year 2020/2021. This research is an experimental research with quasi experimental and category of this research is non-equivalent control group design. The population of this research is the third grade students of SMAN 1 Batulayar consist of 62 students. The instrument that will be used to collect the data is test consists of posttest. The data will be analysed by using statistical formula of t-test. The result of data analysis showed that the value of $t-$ test was 4.39 and t-table 2.00. The value of t-testis higher than t-table in significance level0.05 and degree of freedom 622. It meant that t-critical value was significant fot this confidence level. Then, alternative hypothesis (Ha) was accepeted and null hypothesis (Ho) was rejected. It could be concluded that there was an effect of using snowballing technique to teach vocabulary at the third grade students of SMAN 1 Batulayar in Academic year 2021/2022.
\end{abstract}

Keywords: Snowballing technique; vocabulary

\begin{abstract}
Abstrak
Penggunaan Teknik Bola Salju untuk Belajar Menerapkan Kosakata Setelah Pandemi. Penelitian ini bertujuan untuk mengetahui keefektifan penggunaan teknik bola salju dalam pembelajaran penerapan kosakata pada siswa kelas III SMAN 1 Batulayar tahun ajaran 2020/2021. Penelitian ini merupakan penelitian eksperimen dengan kuasi eksperimen dan kategori penelitian ini adalah non-equivalent control group design. Populasi dalam penelitian ini adalah siswa kelas III SMAN 1 Batulayar yang berjumlah 63 siswa. Instrumen yang akan digunakan untuk mengumpulkan data adalah tes yang terdiri dari post-test. Data tersebut akan dianalisis dengan menggunakan rumus statistik uji-t. Hasil analisis data menunjukkan bahwa nilai uji-t sebesar 4,39 dan t-tabel 2,00. Nilai t-test lebih tinggi dari t-tabel pada taraf signifikansi 0,05 dan derajat bebas 62-2. Artinya nilai t-kritis signifikan terhadap tingkat kepercayaan tersebut. Kemudian, hipotesis alternatif (Ha) diterima dan hipotesis nol (Ho) ditolak. Dapat disimpulkan bahwa ada pengaruh penggunaan teknik bola salju untuk mengajar kosakata pada siswa kelas III SMAN 1 Batulayar Tahun Pelajaran 2021/2022.
\end{abstract}

Kata kunci: Teknik Bola Salju; kosakata

\section{INTRODUCTION}

Vocabulary is challenge for learners, partly because of the size of the task, and partly because of the variety of vocabulary types to be learned including single words, phrases, colocations, and strategic vocabulary as well as grammatical patterning, idioms, and fixed expressions (McCarten, 2007:18). Vocabulary is about words, where they come from, how they change, how they related to each other and how we use them to view the world (Bauer, 2001: VIII). Furthermore, vocabulary could be defined as a dictionary or set of words. This general view is reflected in the lexical graphical approach to the traditional way of listing words in a dictionary (Takac, 2008: 13). A word is a microcosm of human consciousness (Thornby, 2002:1). Vocabulary knowledge is assessed indirectly through the test takers performance of integrative tasks that show how well they can draw on all that language resources to use the language for various communicative purposes (Read, 2000:115). However, search and skills and areas of language may be tested far more effectively by one method then by another. (Heaton, 1989:25)

Vocabulary as one of the subjects that is particularly important in learning English. It means that mastering vocabulary is one of the fundamental way to be good in speaking English. The students who have good vocabulary will be easy to understand and comprehend English. Unfortunately, many students consider in learning vocabulary as a tedious job. Because of that, the teacher should look for an effective technique to make learning vocabulary easier, 
more pleasant, and more enjoyable. The need for vocabulary is one point on which teachers and students agree (Allen, 1983:1)

Techniques are the tools of a teacher. an effective teacher has a multitude of technique and must be able to select the one, which the most efficient to the learners in teaching and learning process. To reach the success in teaching and learning process, teacher needs some teaching techniques like snowballing, it can be the effective technique which can help the teacher to make the student understand about what they need to.

Based on the researchers' observation of the students in SMAN 1 Batulayar, the researchers found the most problem that the students are less in vocabulary., especially applying vocabulary. They got difficulties in giving the meaning of the words or the text and uneasy to use the words in conversation. Moreover, the method of the teacher in teaching vocabulary is not suitable to develop students' vocabulary. They only explain the material to the students. It will cause the students bored in the class.

To overcome the problem of the students, the researchers will use snowballing technique in teaching applying vocabulary. Snowballing is one way to teach vocabulary which is to collect the information from brainstorm, try to think in round, ensuring the full participants and more discussion from the students. The researchers used snowballing technique to make the students active and enjoy in the class with their teacher, and did not make the students bored in the class and easy to understand or memorize the vocabulary. As we know after the pandemic that students mostly should stay and study at home, this will be suitable for them to lose their boring in learning process.

\section{RESEARCH METHOD}

The research method of this study was quasi experimental with non-equivalent control group design by using post-test design only. In this research, the researcher gave different treatments for two groups. The group, which is treated by using snowballing is named experimental group and control group which is treated by using think pair share.
Both groups gave the same post-test. In order to know whether the mean of deviation scores of the two groups in significances. Here are the following the scheme that show in table 01.

Table 01. The Scheme of the Research Design

\begin{tabular}{|c|c|c|}
\hline Group & treatment & post test \\
\hline experimental (R1) & X Snowballing & $\mathrm{X} 1$ \\
\hline control group (R2) & $-\mathrm{X}$ think pair share & $\mathrm{X} 2$ \\
\hline
\end{tabular}

Where:

$$
\begin{array}{ll}
\mathrm{R} 1 & =\text { experimental group } \\
\mathrm{R} 2 & =\text { control group } \\
\mathrm{X} & =\text { treatment of experimental group } \\
-\mathrm{X} & =\text { treatment of control group } \\
\mathrm{X} 1 & =\text { post-test of experimental group } \\
& \mathrm{X} 2 \quad=\text { post-test of control } \\
& \text { group }
\end{array}
$$

\section{Population and Sample \\ Population}

The population is the larger group to which the researcher would like the results of the study to be generalizable (Lodico et al, 2006: 13).

The population of this research is the $2 \mathrm{nd}$ grade of students of SMAN 1 Batulayar in academic year 2020/2021, consist of three classes those are XII.A, XII.B, XII.C comprises of 31 students. So, the total number of populations are 93 students.

\section{Sample}

Sample refer to the part of the universe which is selected for the purpose of investigation (Kothari, 2004 :158).

Sampling technique for this research is cluster random sampling. Cluster random sampling involves grouping the population and then selecting the groups or the clusters rather than individual elements for inclusion in the sample (Kothari, 2004: 16).

In this case, the research used cluster random sampling technique to select the group. From 60 populations, the researcher took two classes as sample, those are class XIIA consist of 31 students as experimental group and class XII.B consist of 31 students as control group. So, the total of the sample is 40 students. The aims of sampling technique is to draw the sample from the population, meanwhile to judge which group as an experimental and control group, the researcher used a lottery. 


\section{Research Instrument}

There are three types of instruments at least in this research. They are multiple choice tests consists of 16 items, for questions rearranging work items and five question gap filling tests which consists of 25 items for both experimental and control group. The test is covered for indicators in for vocabulary, using words, spelling and pronunciation.

The aim of using this test is to find out the difference scores obtained between the control group and the experimental group before and after treatment. Correct answer they get one score, if incorrect answer will get 0 score. So, all items answer correctly, the students get 100 score.

\section{Data Collection}

In this study, data means all information that are directly gathered from the subject. Data obtained from the students after doing the test (instrument) gave to the students. Test itself is a method of measuring a person ability, knowledge performance in a given domain. In this research, researcher used one step for data collection techniques. This step is post-test, researcher giving different treatment between experimental class and control class. For experimental class, researcher taught students vocabulary through snowballing. While for the control class, the researchers taught students vocabulary through think pair share. The result of the test has been counted for the data. In this post-test, the researcher gave 25 items. The result of this test demonstrated the capability of the students after giving a different treatment.

\section{Data Analysis}

Two analysis data, the researcher applies the statistical analysis that is descriptive statistics and inferential statistics. The descriptive used to know the mean, mode, median and standard deviation, whereas the financial statistic to know t-test.

\section{Descriptive Statistics}

a. Mean

Mean also known as arithmetic average, is the most common measure of central tendency and may be defined as the failure which will get by dividing the total of with values of various given items in series by the total number of items by using the formula follow:

$$
\overline{X_{1}}=\frac{\sum X_{1}}{N_{1}} \quad \overline{X_{2}}=\frac{\sum X_{2}}{N_{2}}
$$

Where:

$X_{1}=$ Mean score of the experimental group

$X 2=$ Mean score of the control roup

$\sum X 1=$ The total students' scores of experimental group

$\sum X 2=$ The total students' scores of control group

$N \quad=$ The total number of students

(Miller, 2005: 67)

b. After calculating the mean score, then the researcher determines the median. The median is an alternative measure of the central value of a set of score. It is defined very simply as that value which has as many scores above it as below it:

$$
M e=L+i\left(\frac{\frac{n}{2}-c f b}{f w}\right)
$$

Where:

$\mathrm{L}=$ = the lower limit of the interval within which the median lies $\mathrm{i}=$ interval

$\mathrm{cfb}=$ the cumulative frequency in all interval below the interval containing the median

$\mathrm{fw} \quad=$ the frequency of cases within the interval containing the median

(Anas Sudijono, 2007: 306)

c. The next, the researchers determine the mode. The mode defines as the most frequently occurring value in a set of scores. It can be found very simply by inspection of the data.

$$
M e=L+i\left(\frac{\frac{n}{2}-c f b}{f w}\right)
$$

Where:

$\mathrm{L}=$ the lower limit of the interval within which the median lies $\mathrm{i}=$ interval

$\mathrm{fi} \quad=$ the frequency of the interval containing mode reduced by that of previous interval

$f 2=$ the frequency of the interval containing mode reduced by that of following interval (Anas Sudijono, 2007: 306)

d. Then, the researcher calculating the 
standard deviation of the two groups by using the formula:

Standard deviation of the experimental group:

$$
M e=L+i\left(\frac{\frac{n}{2}-c f b}{f w}\right)
$$

$$
\begin{array}{cl}
\text { Where: } & \\
S_{1} & =\text { Standard deviation for experimental } \\
& \text { group } \\
S 2 & =\text { standard deviation for control group } \\
\sum X 1 & =\text { the total students of experimental group } \\
\sum X 2 & =\text { the total students of control group } \\
N 1 & =\text { the total number of experimental } \\
& \text { students } \\
N 2 & =\text { the total number of control students } \\
X 1 & =\text { the score of experimental students } \\
X 2 & =\text { the score of control students (Miller, } \\
& 2005: 67)
\end{array}
$$

\section{Inferential statistic}

Inferential statistic is used to decide whether the result confirm the predicted effects of independent variable. In other words, this analysis will draw the conclusion whether the scores between the two groups are significant and the use of Snowballing is effective or not. So, in this step, the researcher will substitute the values of $X 1, X 2, S 1, S 2, N 1$,

$$
t=\frac{\left(\bar{X}_{1}-\bar{X}_{2}\right) \sqrt{\left(N_{1}+N_{2}-2\right) N_{1} \cdot N_{2}}}{\sqrt{\left(N_{1} S_{1}^{2}+N_{2} S_{2}^{2}\right)\left(N_{1}+N_{2}\right)}}
$$

$N 2$ in the computational formula for " $t$ " to identify the significant deviation of two mean score:

Where:

$$
\begin{array}{ll}
\bar{X}_{1} & =\text { mean score of experimental score } \\
\bar{X}_{2} \quad=\text { mean score of control score } \\
\sum X_{1} \quad=\text { total of experimental students score } \\
\sum X_{2} \quad=\text { total of control students score } \\
\mathrm{N} \quad=\text { number of students } \\
S_{1}^{2} \quad=\text { standad deviation of } \\
\text { experimental group } \\
S_{2}^{2} \quad=\text { standard deviation of control group }
\end{array}
$$

After that, consult the result between the results of t-test to t-table. If the result or t-test $>\mathrm{t}$-table, the null hypothesis is rejected. If the results of $\mathrm{t}$ - test $<$ t-table than the null hypothesis is accepted (Miller, 2005: 67).

\section{RESEARCH FINDING AND DISCUSSION Research Finding}

\begin{tabular}{|c|c|c|c|c|c|}
\hline \multicolumn{6}{|c|}{$\begin{array}{l}\text { 02. Frequency Distribution } \\
\text { Experimental Group }\end{array}$} \\
\hline $\begin{array}{l}\text { Class } \\
\text { limit }\end{array}$ & $\begin{array}{c}\text { Class } \\
\text { Boundaries }\end{array}$ & $\begin{array}{c}\text { Midpoint } \\
\text { (xi) }\end{array}$ & Tally & $\begin{array}{l}\text { Frequency } \\
\text { (fi) }\end{array}$ & Percentage \\
\hline 64-68 & $63.5-68.5$ & 66 & II & 2 & 6.45 \\
\hline $69-73$ & $68.5-73.5$ & 71 & \#+m+\#+IIII & 13 & 41.93 \\
\hline $74-78$ & $73.5-78.5$ & 76 & H\# I I+\# IIIII & 14 & 45.16 \\
\hline 79-83 & $78.5-83.5$ & 81 & 1 & 1 & 3.22 \\
\hline $84-88$ & $83.5-88.5$ & 86 & 1 & 1 & 3.22 \\
\hline & TOTAL & & & 31 & 100 \\
\hline
\end{tabular}

After the researcher cleared figure by starting analysis. The students score on post-test was join by analyzing the students' result. It's done by counting the score of individual subject. Then the researcher divided the students' score into two groups $\mathrm{X} 1$ as the experimental group used snowballing technique and X2 as control group without snowballing technique.

After getting the score of post-test from the experimental group and control group, the researcher analyzed the data to know some valuable information, such as frequency distribution, mean, median, mode and standard deviation.

\section{Data Description of Experimental Group}

The result of data analysis showed that the high score was 88 and the lowest score was 64 , the mean score was 74.19 , the mode was 73.85 , median was 73.65 , range was 24 , and standard deviation was 15.58 . Then the frequency distribution of data are shown in the table 02 .

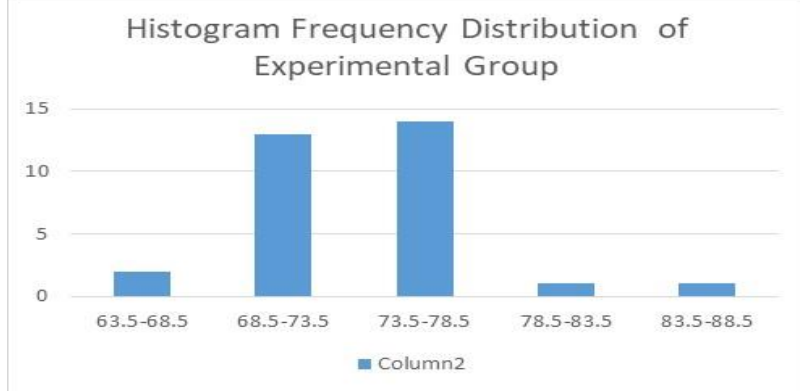

\section{Data Description of Control Group}

The result of data analysis showed that the high score was 84 and the lowest score was 48 , the mean score was 67.61 , the mode was 67.82 , median was 68.38 , range was 36 , and the 
standard deviation was 51.34. then the frequency distribution of data are shown in the table below: Table 03. Frequency Distribution of Control Group

\begin{tabular}{|c|c|c|c|c|c|}
\hline $\begin{array}{c}\text { Class } \\
\text { limit }\end{array}$ & $\begin{array}{c}\text { Class } \\
\text { Boundaries }\end{array}$ & $\begin{array}{c}\text { Midpoint } \\
\text { (xi) }\end{array}$ & Tally & $\begin{array}{c}\text { Frequency } \\
\text { (fi) }\end{array}$ & Percentage \\
\hline $48-55$ & $47.5-55.5$ & 51 & I & 1 & 3.22 \\
\hline $56-63$ & $55.5-63.5$ & 59 & IIII & 4 & 12.96 \\
\hline $64-71$ & $63.5-71.5$ & 67 & $\begin{array}{c}\text { Hf IfH IIIt } \\
\text { II }\end{array}$ & 17 & 54.83 \\
\hline $72-79$ & $71.5-79.5$ & 75 & +fI I & 6 & 19.35 \\
\hline $80-87$ & $79.5-87.5$ & 83 & III & 3 & 9.67 \\
\hline
\end{tabular}

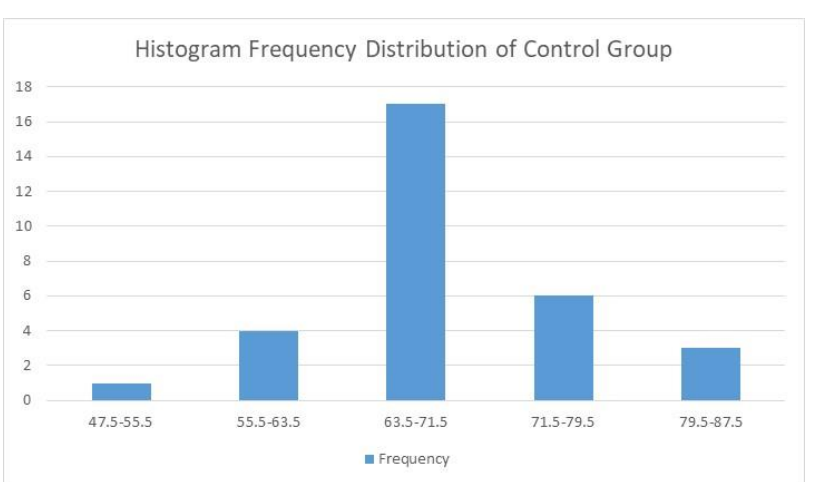

\section{Testing Hypothesis}

This research answered the problem of study to find out the effective of snowballing technique to teach vocabulary at the third grade students of SMAN 1 Batulayar in academic year 2020/2021. To get the answer the researcher compared the value of t-test and the value of t-table and if the criteria hypothesis presentation states that: if the value of t-test is higher than t-table, the hypothesis alternative (Ha) the snowballing technique was effective to teach English applying vocabulary at the third grade students' of SMAN 1 Batulayar in academic year 2020/2021 was received. The value of t-test is lowest than t-table the null hypothesis (Ho) snowballing technique is not effective to teach English applying vocabulary at the third grade students of SMAN 1 Batulayar in academic year 2020/2021 was rejected.

After the researcher analyzed t-test and ttable, the researcher found that the value of t-test is higher than t-table (4.39>2.00) at significance level 0.05 . This result shown the alternative hypothesis $(\mathrm{Ha})$ is received and null hypothesis (Ho) was rejected. So using snowballing technique is effective because the technique that used by researcher is suitable to teach vocabulary.

\section{Discussion}

The computations the correlation between two mean deviation scores of the groups have consulted to the value of the t-table. However before it was consulted the writer needs to determine the level of significance and the degree of freedom used in this study. The value of critical value of " $t$ " to test the significance of the two variables were being investigated, the critical value of " $t$ " then consulted to the $t$-table (t-interpretation) at the degree of freedom (df) for $(62-2=60)$ at the confidence level of 0.05 which the t-table equal 2.00, the comparison is done between t-test formula with t-table in which the result of t-test is 4.39 it is found out that the table of " $\mathrm{t}$ " indicates : $\mathrm{Ho}=\mathrm{t}$-test $=4.39>\mathrm{t}$ table $=2.00(0.05)$.

Based on the data above, it is obtained that the criteria value of t-test is higher than $\mathrm{t}$ table. Degree of freedom of 60 at confidence level 0.05 with 2.00 in fact, the $t$-critical value is significance. So, the researcher may take a conclusion that Alternative Hypothesis (Ha) which reads The snowballing technique have positive effect to teach applying vocabulary at the third grade students of SMAN 1 Batulayar was clearly accepted, and Null Hypothesis (Ho) was rejected.

From the data above it can be concluded that the use of snowballing technique is effective to teach vocabulary at the third grade students' of SMAN 1 Batulayar in academic year 2020/2021, because technique that used by researcher was suitable for teaching applying vocabulary.

\section{CONCLUSION}

The result of the study has been known as well. That the teaching applying vocabulary by using snowballing technique was effective for the students of SMAN 1 Batulayar. Therefore, there are some main points of research that must be concluded, such as:

1. The result of mean score in experimental group was 74.19 and the result of mean score in control group was 67.61

2. Using snowballing technique is more effective than not using snowballing technique, it showed that the Alternative 
Hypothesis (Ha) was accepted and Null Hypothesis (Ho) was rejected.

Finally, the analysis and the interpretation of data eventually lead the researcher to the conclusion that the use of snowballing technique has positive effect for teaching applying vocabulary at the third grade students of SMAN 1 Batulayar in English subject. It can be provided by the result of experimental group, post-test which got higher than the control group.

\section{SUGGESTION}

The teacher should innovative in finding new technique or strategy that mahe the students learning English easier. Snowballing technique is one technique that is suitable for students to increase their ability to mastering vocabulary. There are a lot of tehniques that teachers should apply for the process of teaching and learning English in the classroom.

\section{THANK GIVING}

Thank you for LPPM Universitas Pendidikan Mandalika that support our financial so this research had been done succesfully. Also thanks for the headquarter, teachers, and staff of SMAN 1 Batulayar that welcome us to do the research at their school.

\section{REFERENCES}

Allen, Virginia French. 1983. Techniques in Teaching Vocabulary. New York: Oxford University Press.

an Experimental Research. Thesis, Unpublished. IKIP Mataram.

Annas Sudijono. 2007. Pengantar Statistik Pendidikan. PT Raja Grafindo

Ariyanto. 2012. The Effect of Using Snowball Drilling Method toward the

Artono, W. Masduki B, J. and Sukirman, D. 2008. English in Focus for Grade VIII. Jakarta: Departement Pendidikan Nasional.

Bauer, Laurie. 2001. Vocabulary. New York: Routledge.

Brown, H Douglas. 2003. Language Assessment Principles and Classroom Practice. California: Longman.

Febrianti, Yulia. 2012. The Effectiveness of Ball Games in Teaching
H. Hiebert, Elfrida \& L. Kamil, Micheal. 2005. Teaching \& Learning

Heaton, J. B. 1989. Writing English Language Teaching. New York: Longman.

Institut Keguruan dan Ilmu Pendidikan. IKIP Mataram. Unpublished.

Khotari. 2004. Research Methodology. New Age International Publisher: New Delhi.

Language Acquisition. England: Multilingual Matters.

Lessons from the Classroom. USA: Cambridge University Press.

Lodico, Marguerite, Spaulding, Dean $\mathrm{T} \&$ Voegtle, Katherine H. 2006.

Mc Carten, Jeanne. 2007. Teaching Vocabulary. Lessons from the Corpus.

Methods in Educational Research from Theory to Practice. U.S.A: Jossey Bass.

Miller, Stave. 2005. Experimental Design and Statistic. Second Edition. London and New York: Routledge.

Nigel Fisher. 2012. Improving Teaching and Learning. UK: The Students Room Group.

Persada Jakarta. In Fathurrahaman Imran. 2013. Simples Statistic.

Read, John. 2000. Assessing Vocabulary. UK: Cambridge University Press.

Students Vocabulary Achievement. Thesis, Unpublished. Panca Sakti Tegal.

Sukron Ma'mun. 2013. The Effectiveness of Jigsaw in Teaching Vocabulary

Takac , Pacific Vinsja. 2008. Vocabulary Learning Strategies and Foreign

Thornburry, Scott. 2002. How to Teach Vocabulary. England: Pearson Education Limited.

Vocabulary Bringing Research to Practice. New Jersey: Lawrence Erlbaum Associates, Publisher.

Vocabulary. Thesis, Unpublished. IKIP Mataram. 